\title{
PERTUMBUHAN DAN HASIL PADI SIRANTAU PADA PEMBERIAN BEBERAPA MACAM DAN DOSIS PUPUK KANDANG
}

\author{
Ringki Putra Azalika1, Sumardi ${ }^{1 *}$, Sukisno ${ }^{2}$ \\ ${ }^{1}$ Program Studi Agroekoteknologi, Fakultas Pertanian, Universitas Bengkulu \\ ${ }^{2}$ Program Studi Ilmu Tanah, Fakultas Pertanian, Universitas Bengkulu \\ * Corresponding Author : sumardi@unib.ac.id
}

\begin{abstract}
[GROWTH AND YIELDS OF "SIRANTAU" RICE AT VARIOUS TYPES AND DOSAGES OF ANIMALWASTED MANURES]. Growing a drought tolerant rice variety in sub-optimal agricultural lands might be considered as strategic effort to increase rice production. This experiment aimed to determine type and optimum dosage of animal-wasted fertilizer for 'Sirantau' rice variety. A potted factorial experiment of complete randomized design with three replicates was conducted from January to May 2016 at Experimental Sites of Faculty of Agriculture, University of Bengkulu. The first factor was type of animal-wasted manures, cattle, goat and poultry, while the second factor was dosage of animal-wasted manures, 5, 10, 15, 20 and 25 ton/ha. Variable of observations consisted of plant height, number of total tiller, number of productive tiller, length of panicle, number of rice grain per panicle, percentage of filled rice grain, weight of dried 100 grains, and dry weight of rice grain plant ${ }^{-1}$. Results indicated that types of animal-wasted manures significantly affected number of total tiller, number of productive tiller and dry weight of rice grain/plant. Poultry-based manure with 10 ton/ha produced the best rice yield with yield potential of $123.13 \mathrm{~g} /$ plant (5.77 ton/ha).
\end{abstract}

Keyword: Rice, Sirantau variety, Animal-wasted fertilizer

\begin{abstract}
ABSTRAK
Salah satu upaya peningkatan produksi padi adalah dengan pengembangan pertanian di lahan - lahan sub optimal dengan penanaman varietas padi yang toleran kekeringan seperti kultivar sirantau. Penelitian ini bertujuan untuk menentukan jenis dan dosis pupuk kandang yang optimum untuk pertumbuhan dan hasil padi Sirantau. Penelitian telah dilaksanakan dari bulan Januari hingga Mei 2016 di Kebun Percobaan Fakultas Pertanian Universitas Bengkulu. Penelitian ini merupakan percobaan pot faktorial dua faktor, menggunakan Rancangan Acak Lengkap. Faktor pertama adalah jenis pupuk kandang, yaitu pupuk kandang sapi, pupuk kandang kambing, pupuk kandang ayam. Faktor kedua adalah dosis pupuk kandang, yaitu 5 ton/ha, 10 ton/ha, 15 ton/ha, 20 ton/ha, dan 25 ton/ha, masing - masing perlakuan diulang sebanyak 3 kali. Variabel yang diamati meliputi tinggi tanaman, jumlah anakan total, jumlah anakan produktif, panjang malai, jumlah bulir per malai, persentase bulir bernas, bobot 100 gabah kering, dan bobot gabah kering per rumpun. Hasil penelitian menunjukkan bahwa jenis pupuk kandang memberikan pengaruh nyata terhadap variabel jumlah anakan total, jumlah anakan produktif dan bobot gabah kering per rumpun. Pupuk kandang ayam dengan dosis 10 ton/ha memberikan hasil padi terbaik dengan potensi hasil 123,13 g/rumpun (5,77 ton/ha).
\end{abstract}

Kata kunci: padi, varietas Sirantau, pupuk kandang 


\section{PENDAHULUAN}

Indonesia yang dikenal dengan negara agraris yang sedang menghadapi kondisi kemunduran peningkatan produksi pangan sehingga dikhawatirkan terjadinya krisis pangan. Kebutuhan bahan pangan beras meningkat dari tahun ke tahun seiring dengan terus meningkatnya jumlah penduduk. Laju pertumbuhan penduduk Indonesia pada tahun 2014 adalah sekitar 1,52\%, sedangkan persentase produksi padi pada tahun 2014 mengalami penurunan sekitar 0,43\% (BPS, 2015). Penurunan produksi padi di Indonesia antara lain disebabkan oleh alih fungsi lahan sawah menjadi lahan kelapa sawit (Utomo, 1992). Dengan demikian, perlu upaya pemanfaatan lahan - lahan sub optimal dengan penanaman varietas padi yang toleran terhadap kondisi yang kurang optimal.

Lahan sub-optimal kering masam memiliki berbagai kendala, di antaranya adalah kandungan bahan organik rendah, ketersediaan air rendah, keasaman tanah tinggi ( $\mathrm{pH}$ rendah), dan sangat miskin unsur hara. Lahan kering juga memiliki tingkat kesulitan yang tinggi dalam pengolahan lahan dan pemilihan varietas yang adaptif terhadap kondisi kekeringan (Kukuh \& Anwar, 2014). Salah satu upaya meningkatkan produksi lahan sub optimal yaitu dengan cara pemberian bahan organik yang ada dalam pupuk kandang. Pupuk kandang yang biasa digunakan di antaranya adalah pupuk kandang sapi, pupuk kandang kambing dan pupuk kandang ayam. Hardjowigeno (2003) menyatakan bahwa kandungan hara pada pupuk kandang ayam atau unggas yaitu $\mathrm{N} 1,0 \%, \mathrm{P}_{2} \mathrm{O}_{5} 0,80 \%$, dan $\mathrm{K}_{2} \mathrm{O}$ $0,40 \%$. Pupuk kandang sapi dan kambing yang memiliki kandungan hara berturut - turut sebesar $\mathrm{N}$ $0,40 \%, \mathrm{P}_{2} \mathrm{O}_{5} 0,20 \%, \mathrm{~K}_{2} \mathrm{O} 0,10 \%$ dan $\mathrm{N} 0,60 \%, \mathrm{P}_{2} \mathrm{O}_{5}$ $0,30 \%$, dan $\mathrm{K}_{2} \mathrm{O} 0,17 \%$.

Padi gogo merupakan salah satu ragam padi yang penanamannya dapat dilakukan pada lahan sub optimal. Padi gogo lokal memiliki beberapa keunggulan yang tidak dimiliki oleh kultivar unggul nasional seperti toleran terhadap kekeringan, tahan hama dan penyakit, serta sebagian memiliki sifat aromatik (Sumartono et al., 1983). Salah satu kultivar padi gogo lokal yang memiliki sifat adaptif pada lahan marginal kering dan aromatik adalah padi Sirantau. Padi Sirantau merupakan padi gogo yang berkembang di Desa Tanjung Tebat, Kecamatan Bunga Mas, Kabupaten Bengkulu Selatan, Provinsi Bengkulu. Penelitian ini bertujuan untuk menentukan jenis dan dosis pupuk kandang yang optimum untuk pertumbuhan dan hasil padi Sirantau.

\section{METODE PENELITIAN}

Penelitian telah dilaksanakan dari bulan Januari hingga Mei 2016 di Kebun Percobaan Fakultas Pertanian Universitas Bengkulu. Bahan tanam yang digunakan yaitu benih padi Sirantau, tanah Ultisol, polibag berukuran $10 \mathrm{~kg}$, pupuk kandang kotoran sapi, pupuk kandang kotoran kambing dan pupuk kandang kotoran ayam.

Penelitian ini merupakan percobaan pot faktorial dua faktor, menggunakan disain Rancangan Acak Lengkap. Faktor pertama yaitu jenis pupuk kandang kandang: (1) kotoran sapi, (2) kotoran kambing, dan (3) kotoran ayam. Faktor kedua adalah dosis pupuk kandang, yaitu 5 ton/ha, 10 ton/ha, 15 ton/ha, 20 ton/ ha, dan 25 ton/ha, masing-masing perlakuan diulang sebanyak 3 kali. Sebagai pembanding ditanam 3 tanaman kontrol (tanpa perlakuan).

Media tanam berupa tanah jenis Ultisol yang diambil dari lahan pertanian Universitas Bengkulu pada kedalaman 0 sampai $20 \mathrm{~cm}$ dari atas permukaan tanah. Tanah kemudian dihaluskan, dikering anginkan dan diayak menggunakan ayakan berdiameter 2,0 $\mathrm{mm}$. Tanah hasil ayakan ditimbang sebanyak $10 \mathrm{~kg}$ dengan kadar air sebesar 14\%. Tanah dan pupuk kandang dicampur berdasarkan perlakuan. Polibag yang sudah terisi media tanam disusun dengan jarak 25 $\mathrm{cm}$ x $25 \mathrm{~cm}$ antar perlakuan. Penanaman dilakukan dengan cara membuat lubang tanam dengan menggunakan tugal dengan kedalaman $2 \mathrm{~cm}$. Penjarangan tanaman padi dilakukan setelah tanaman berumur 14 hari dan hanya disisakan 2 tanaman padi yang pertumbuhannya lebih baik. Tanaman diberi pupuk dasar urea $(46 \%$ $\mathrm{N})$, TSP $\left(46 \% \mathrm{P}_{2} \mathrm{O}_{5}\right)$ dan $\mathrm{KCl}\left(60 \% \mathrm{~K}_{2} \mathrm{O}\right)$ sebanyak $25 \%$ dari dosis anjuran. Pemanenan dilakukan setelah tanaman menunjukkan kriteria panen, yakni $85 \%$ malai padi sudah berwarna kuning keemasan, daun bendera dan bulir padi $90 \%$ telah menguning, dan malai padi merunduk, serta butir gabah keras jika ditekan dengan menggunakan jari.

Variabel yang diamati yaitu tinggi tanaman, jumlah anakan total, jumlah anakan produktif, panjang malai, jumlah bulir per malai, persentase bulir bernas, bobot 100 gabah kering, dan bobot gabah kering per rumpun. Data yang diperoleh dianalisis secara statistik dengan menggunakan analisis varian dan jika hasil analisis menunjukkan ada pengaruh nyata, maka dilakukan uji Beda Nyata Terkecil pada taraf 5\% (Yitnosumarto, 1991).

\section{HASIL DAN PEMBAHASAN}

Hasil analisis data menunjukkan bahwa perlakuan jenis pupuk kandang hanya berpengaruh nyata $(\mathrm{P} \leq$ $0,05)$ pada variabel jumlah anakan total, jumlah anakan produktif dan bobot gabah kering per rumpun. Sedangkan, dosis pupuk kandang berpengaruh tidak nyata $(P>0,05)$ pada semua variabel yang diamati. Demikian juga, interaksi antara perlakuan jenis dan dosis pupuk kandang juga berpengaruh tidak nyata pada semua variabel pengamatan.

Pertumbuhan tanaman merupakan suatu penambahan ukuran tanaman atau bagian tanaman yang memiliki sifat tidak dapat kembali pada sifat sebelumnya, 
yang diikuti oleh perubahan bentuk dan ukuran tanaman (Sarjana \& Utami, 2001). Komponen pertumbuhan tanaman mempengaruhi komponen hasil tanaman. Semakin baik pertumbuhan tanaman maka akan semakin baik pula hasil tanaman yang didapat.

Tinggi tanaman merupakan salah satu faktor yang paling terlihat yang bisa dijadikan acuan untuk melihat pengaruh perlakuan. Perbedaan tinggi tanaman selain ditentukan kondisi lingkungan juga dipengaruhi perlakuan yang diberikan. Tinggi tanaman pada 15 mst disajikan pada Tabel 1 .

Tabel 1. Rata - rata tinggi tanaman pada $15 \mathrm{mst}$ akibat pemberian jenis dan dosis pupuk kandang

\begin{tabular}{|c|c|c|}
\hline \multirow{2}{*}{$\begin{array}{l}\text { Jenis pupuk } \\
\text { kandang }\end{array}$} & \multicolumn{2}{|c|}{ Tinggi tanaman $(\mathrm{cm})$} \\
\hline & $15 \mathrm{mst}$ & $\begin{array}{l}\text { Selisih dengan } \\
\text { kontrol }\end{array}$ \\
\hline \multicolumn{3}{|l|}{ Kotoran Sapi } \\
\hline 5 ton ha & 122,53 & $31,93(35,25 \%)$ \\
\hline 10 ton $/$ ha & 114,43 & $23,83(26,31 \%)$ \\
\hline 15 ton ha & 114,50 & $23,90(26,38 \%)$ \\
\hline 20 ton ha & 106,87 & $16,27(17,95 \%)$ \\
\hline 25 ton $/$ ha & 108,47 & $17,87(19,72 \%)$ \\
\hline \multicolumn{3}{|l|}{$\begin{array}{l}\text { Kotoran } \\
\text { Kambing }\end{array}$} \\
\hline 5 ton ha & 127,10 & $36,50(40,29 \%)$ \\
\hline 10 ton $/$ ha & 114,97 & $24,37(26,89 \%)$ \\
\hline 15 ton ha & 117,30 & $26,70(29,47 \%)$ \\
\hline 20 ton $/$ ha & 117,30 & $26,70(29,47 \%)$ \\
\hline 25 ton $/$ a & 116,97 & $26,37(29,10 \%)$ \\
\hline \multicolumn{3}{|l|}{ Kotoran } \\
\hline Ayam & & \\
\hline 5 ton ha & 120,20 & $29,60(32,67 \%)$ \\
\hline 10 ton $/$ ha & 120,60 & $30,00(33,11 \%)$ \\
\hline 15 ton $/$ ha & 113,40 & $22,80(25,17 \%)$ \\
\hline 20 ton ha & 117,23 & $26,63(29,40 \%)$ \\
\hline 25 ton $/$ ha & 112,17 & $21,57(23,80 \%)$ \\
\hline Kontrol & 90,60 & \\
\hline
\end{tabular}

Secara kuantitatif terdapat perbedaan kenaikan tinggi tanaman padi pada setiap perlakuan. Menurut Putra (2012), pemberian pupuk, baik jenis atau dosis memengaruhi pertumbuhan dan hasil tanaman padi. Namun demikian, menurut Rahayu \& Harjoso (2011), pengaruh terhadap pertumbuhan tanaman bukan hanya karena faktor pemberian pupuk tetapi faktor varietas juga sangat berpengaruh. Sedangkan Hoque et al. (2003) dan Warda (2011) menyatakan bahwa tinggi tanaman sangat dipengaruhi varietas dan galur yang memiliki adaptasi yang lebih baik terhadap lingkungan .

Anakan merupakan produk dari fase vegetatif tanaman yang menentukan hasil panen tanaman padi. Menurut Yoshida (1981), anakan padi merupakan indikator pertumbuhan tanaman padi yang sehat atau sakit, meskipun secara genetik varietas tanaman menentukan jumlah anakan dan peranan $\mathrm{N}$ sangat penting dalam proses pertumbuhan jumlah anakan. Jumlah anakan total pada $15 \mathrm{mst}$ disajikan pada Tabel 2.

Tabel 2. Rata-rata jumlah anakan total pada $15 \mathrm{mst}$ akibat pemberian jenis dan dosis pupuk kandang

\begin{tabular}{ccc}
\hline \multirow{2}{*}{ Jenis pupuk kandang } & \multicolumn{2}{c}{ Jumlah anakan total (batang) } \\
\cline { 2 - 3 } Kotoran Sapi & $15 \mathrm{mst}$ & Selisih dengan kontrol \\
\hline 5 ton $/$ ha & 13,67 & $6,00(78,18 \%)$ \\
10 ton $/$ ha & 11,33 & $3,66(47,76 \%)$ \\
15 ton $/$ ha & 12,33 & $4,66(60,80 \%)$ \\
20 ton $/$ ha & 10,00 & $2,33(30,38 \%)$ \\
25 ton $/$ ha & 12,00 & $4,33(56,45 \%)$ \\
\hline Kotoran Kambing & & \\
5 ton $/$ ha & 15,00 & $7,33(95,57 \%)$ \\
10 ton $/$ ha & 12,33 & $4,66(60,80 \%)$ \\
15 ton $/$ ha & 13,33 & $5,66(73,84 \%)$ \\
20 ton $/$ ha & 11,67 & $4,00(52,11 \%)$ \\
25 ton $/$ ha & 14,33 & $6,66(86,88 \%)$ \\
\hline Kotoran Ayam & & \\
5 ton $/$ ha & 13,33 & $5,66(73,84 \%)$ \\
10 ton $/$ ha & 20,00 & $12,33(160,76 \%)$ \\
15 ton $/$ ha & 15,33 & $7,66(99,91 \%)$ \\
20 ton $/$ ha & 19,33 & $11,66(152,06 \%)$ \\
25 ton $/$ ha & 16,33 & $8,66(112,95 \%)$ \\
\hline Kontrol & 7,67 & \\
\hline
\end{tabular}

Secara kuantitatif terlihat bahwa jenis dan dosis pupuk kandang menghasilkan jumlah anakan total tanaman padi yang berbeda (Tabel 2). Pemberian perlakuan jenis pupuk kandang berpengaruh nyata terhadap jumlah anakan total tanaman padi Sirantau (Tabel 3). Hal ini disebabkan karena dalam proses pembentukan anakan tanaman lebih banyak membutuhkan unsur P. Menurut Handojo (1991), salah satu fungsi unsur hara $\mathrm{P}$ adalah untuk merangsang akar dan batang tanaman padi serta memperbesar pembentukan anakan. Kandungan hara pada pupuk kandang kotoran ayam lebih banyak dibandingkan pupuk kandang kotoran sapi dan kambing.

Anakan produktif adalah anakan yang menghasilkan malai dan terbentuk setelah tanaman memasuki fase generatif. Hasil pengamatan menunjukkan bahwa 99\% jumlah anakan total menjadi anakan produktif, berarti perlakuan yang diberikan kepada tanaman sudah mencukupi kebutuhan anakan tanaman untuk mengeluarkan malai.

Pupuk kandang kotoran ayam memberikan pengaruh lebih baik pada variabel jumlah anakan total dan jumlah anakan produktif. Pada variabel jumlah anakan total, pupuk kandang kotoran ayam memberikan rata - rata jumlah anakan total sebanyak 16,8 batang, lebih banyak $42,37 \%$ bila dibandingkan 
dengan pemberian perlakuan pupuk kandang kotoran sapi yang memberikan pengaruh terendah yaitu rata rata 11,8 batang. Demikian juga pada variabel jumlah anakan produktif, perlakuan jenis pupuk kandang kotoran ayam memberikan jumlah anakan produktif tertinggi yaitu 16,6 batang, lebih banyak 41,88\% bila dibandingkan dengan perlakuan pupuk kandang kotoran sapi yang memberikan rata-rata jumlah anakan produktif terendah sebesar 11,7 batang.

Tabel 3. Rata-rata jumlah anakan akibat pemberian jenis pupuk kandang

\begin{tabular}{lll}
\hline Jenis pupuk kandang & $\begin{array}{l}\text { Jumlah anakan total } \\
\text { (batang) }\end{array}$ & $\begin{array}{l}\text { Jumlah anakan produktif } \\
\text { (batang) }\end{array}$ \\
\hline Kotoran sapi & $11,8 \mathrm{~b}$ & $11,7 \mathrm{~b}$ \\
Kotoran kambing & $13,3 \mathrm{~b}$ & $13,3 \mathrm{ab}$ \\
Kotoran ayam & $16,8 \mathrm{a}$ & $16,6 \mathrm{a}$ \\
\hline
\end{tabular}

Keterangan : angka-angka yang diikuti oleh huruf yang sama pada kolom yang sama berbeda tidak nyata pada BNT 5\% .

Howard et al. (2001) menyatakan tanaman serealia memerlukan unsur hara $\mathrm{N}$ dan $\mathrm{K}$ yang dapat memacu proses fotosintesis memasuki fase generatif khususnya untuk pembentukan anakan yang menghasilkan malai. Marschner (1995) juga menyatakan bahwa unsur hara yang tersedia cukup dalam tanah terutama $\mathrm{N}$, P dan $\mathrm{K}$ dapat merangsang pembentukan anakan dan anakan produktif.

Menurut Joesron \& Fathorrozi (2003) hasil tanaman berkaitan dengan cara bagaimana sumber daya dipergunakan untuk menghasilkan sumber daya atau produk. Hasil padi gogo merupakan akumulasi fotosintat pada tanaman padi gogo. Penelitian Ginting et al. (2015) menunjukkan bahwa pemberian pupuk organik dapat meningkatkan jumlah anakan, jumlah anakan produktif dan jumlah bulir per malai serta produksi gabah per petak.

Panjang malai merupakan komponen penting dalam penentuan hasil tanaman dimana semakin panjang malai maka diharapkan semakin banyak jumlah bulir. Zeany (2007) menyatakan interaksi antara tanaman padi dengan faktor lingkungan dapat mempengaruhi pertumbuhan dan hasil tanaman padi. Panjang malai masingmasing perlakuan dapat dilihat pada Gambar 1 .

Malai yang terbentuk memiliki panjang ratarata $28,38 \mathrm{~cm}$ pada pemberian pupuk kandang kotoran kambing dengan dosis 20 ton/ha (Gambar 1). Hasil ini lebih besar 25,57\% bila dibandingkan dengan tanpa pemberian pupuk kandang (kontrol). Malai terbentuk ketika memasuki fase generatif, pada fase ini padi memerlukan ketersediaan air yang cukup dan kebutuhan unsur $\mathrm{N}$ yang tersedia bagi tanaman karena pada fase ini juga sel - sel tanaman sangat aktif membelah dan proses pembelahan akan semakin baik jika suplai $\mathrm{N}$ tersedia bagi tanaman. Mega et al. (1970) menyatakan bahwa terbentunya malai betina dipengaruhi oleh suplai nitrogen stadia pemisah sel sel primordial buku leher malai. Panjang malai akan semakin meningkat jika pemberian pupuk kandang kotoran ayam pada dosis yang tepat bagi tanaman.

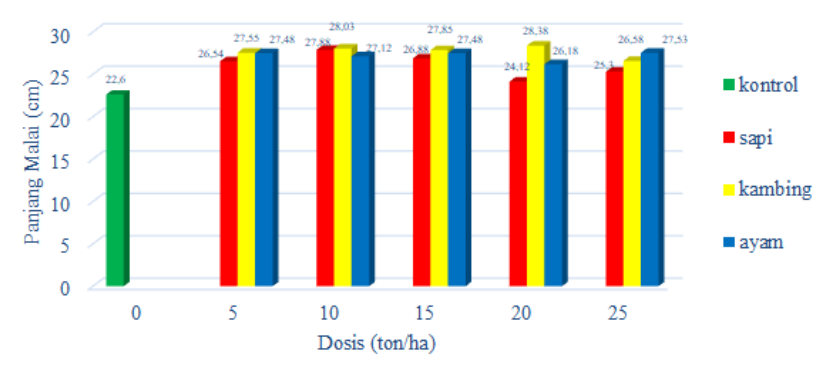

Gambar 1. Rata-rata panjang malai padi Sirantau

Jumlah bulir per malai merupakan banyaknya bulir yang terbentuk dalam satu malai. Jumlah bulir per malai juga menjadi penentu bobot hasil tanaman. Semakin banyak jumlah bulir per malai diharapkan akan menambah hasil produksi tanaman, sedangkan jumlah bulir per malai juga di tentukan oleh panjang malai. Jumlah bulir per malai masing - masing perlakuan dapat dilihat pada Gambar 2.

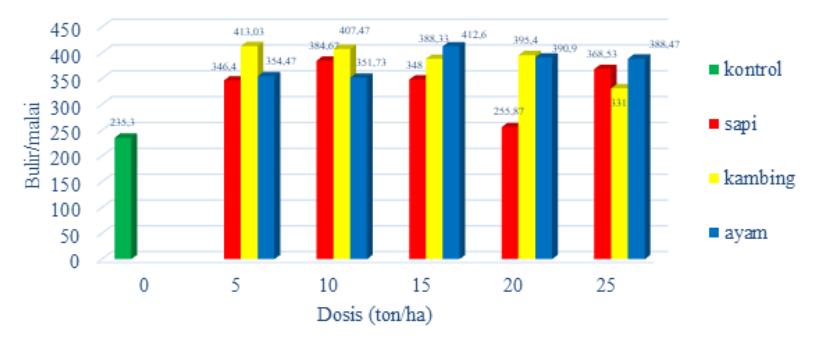

Gambar 2. Rata-rata jumlah bulir per malai padi Sirantau

Pemberian pupuk kandang kotoran kambing pada dosis 5 ton/ha menghasilkan jumlah bulir terbanyak dengan rata - rata 413,03 bulir per malai atau meningkat $75,53 \%$ bila dibandingkan dengan tanpa pemberian pupuk kandang (kontrol) (Gambar 2). De Datta (1981) menyatakan bahwa ketidakseimbangan antara $\mathrm{N}$ dan $P$ serta ketersedian air bagi tanaman akan mempengaruhi jumlah bulir/gabah yang terbentuk. Unsur P ditemukan relatif dalam jumlah lebih banyak dalam buah dan biji tanaman (Rosmarkam \& Yuwono, 2002). Unsur hara $\mathrm{P}$ banyak terkandung dalam pupuk kandang kotoran ayam yaitu sebesar 0,80\% (Hardjowigeno, 2003). Selain hara $\mathrm{P}$, banyaknya malai yang terbentuk juga dipengaruhi oleh ketersediaan air pada saat pembentukan bulir. 
Persentase bulir bernas merupakan perbandingan antara bulir bernas dan bulir hampa dalam satuan persen (\%). Persentase bulir bernas sangat berpengaruh dengan bobot hasil tanaman, serta persentase bulir bernas dipengaruhi oleh faktor internal seperti gen genotipe/varietas dan kebutuhan hara tanaman dan faktor eksternal seperti serangan hama pengganggu tanaman (walang sangit). Serangan walang sangit mengakibatkan pertumbuhan bulir kurang sempurna, biji/bulir tidak terisi penuh bahkan tidak terisi/hampa sama sekali (Willis, 2001).

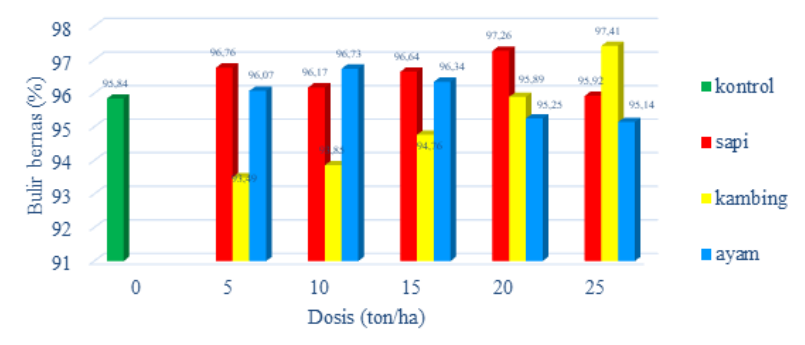

Gambar 3. Rata - rata persentase bulir bernas padi Sirantau

Pupuk kandang kotoran sapi dengan dosis 20 ton/ha memberikan persentase bulir bernas sekitar $97,26 \%$ yang lebih tinggi bila dibandingkan dengan tanpa pemberian pupuk kandang (kontrol) (Gambar $3)$. Keseimbangan antara pupuk dasar dan perlakuan pupuk kandang yang diberikan juga berpengaruh, sehingga pada saat proses pengisian gabah berjalan dengan optimal dikarenakan tercukupinya kebutuhan tanaman akan unsur hara walaupun tidak memberikan pengaruh yang signifikan pada semua taraf dosis perlakuan. Penambahan pupuk kandang yang dilakukan pada saat tanaman memasuki fase generatif berhasil mencukupi kubutuhan unsur hara tanaman. Hasil penelitian yang dilakukan oleh Sari et al. (2017), menyimpulkan bahwa pemberian pupuk kandang kotoran ayam tidak memberikan pengaruh nyata terhadap pertumbuhan awal (tinggi tananam, jumlah daun, jumlah anakan, dan jumlah anakan produktif) tanaman padi.

Perlakuan jenis dan dosis pupuk berpengaruh tidak nyata $(\mathrm{P}>0,05)$ pada variabel bobot 100 biji gabah kering pada kadar air 12\%. Hal ini disebabkan ukuran bulir yang relatif seragam pada tanaman padi Sirantau, dengan ukuran bulir dan kadar air yang relatif sama mengakibatkan bobot bulir akan sama. Sumardi (2007) menyatakan bobot kering 100 biji ditentukan oleh genetiknya, tapi faktor lingkungan juga berpengaruh terhadap faktor pembentukan berat bijinya. Faktor lingkungan dan daya serap hara tanaman juga berpengaruh penting pada bobot gabah. Ratarata bobot 100 biji gabah kering masing-masing perlakuan dapat dilihat pada Gambar 4.
Pemberian pupuk kandang kotoran sapi pada dosis 5 ton/ha menghasilkan bobot 100 biji gabah kering seberat $1,89 \mathrm{~g}$ yang meningkat $32,16 \%$ bila dibandingkan dengan tanpa pemberian pupuk kandang (kontrol). Perbedaan yang kecil ini menunjukkan bahwa pemberian beberapa jenis pupuk kandang telah memenuhi kebutuhan tanaman. Sarif (1986) menyatakan bahwa proses fotosintesis yang berjalan dengan baik sebagai akibat adanya $\mathrm{P}$ juga akan meningkatkan hasil fotosintesa yang ditransfer ke dalam biji. Bobot gabah padi sangat berhubungan erat dengan proses fotosintesis yang terjadi pada daun.

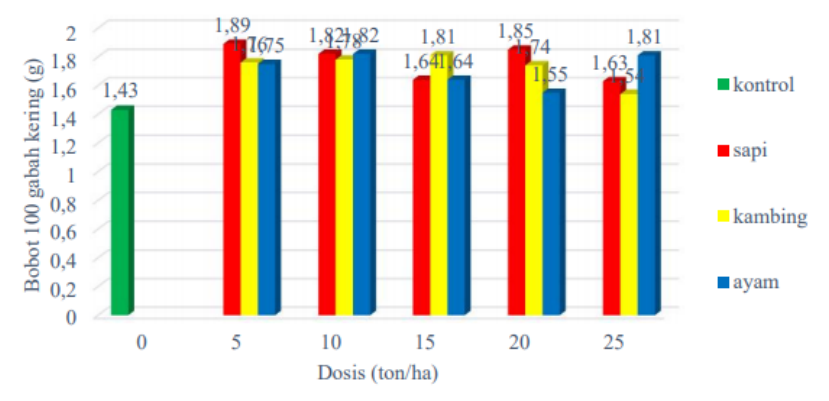

Gambar 4. Rata - rata bobot 100 biji gabah kering padi Sirantau

Gabah kering merupakan gabah yang sudah dikeringkan hingga kadar air 12\%. Bobot gabah kering per rumpun merupakan total bobot bulir dalam satu rumpun tanaman padi. Bobot gabah kering per rumpun dipengaruhi oleh jumlah anakan total, jumlah anakan produktif, panjang malai, jumlah bulir per malai, dan persentase bulir bernas hingga bobot 100 gabah kering. Oleh karena itu semakin banyak jumlah anakan akan berpengaruh terhadap jumlah anakan produktif. Sumardi (2007) menyatakan bahwa hasil bobot gabah kering per rumpun berkaitan dengan jumlah anakan total. Sedangkan Hoque et al. (2003), menyatakan pemberian bahan organik secara nyata memperbaiki pertumbuhan tanaman padi. Hasil penelitian ini menunjukkan bahwa jenis pupuk kotoran sapi dan kotoran kambing secara rata-rata menghasilkan bobot gabah kering per rumpun masing-masing $68,53 \mathrm{~g}$ dan $84,39 \mathrm{~g}$. Bobot gabah kering per rumpun tersebut nyata lebih rendah jika dibandingkan dengan jenis pupuk kotoran ayam yang mampu menghasilkan rata-rata sebesar 102,35 g.

Menurut Uchida (2000), unsur K merupakan aktivator beberapa enzim dalam metabolisme tanaman dan untuk pembentukan ATP (adenosine triphosphate) dan berperan dalam menentukan ukuran gabah. Jika kebutuhan unsur K tidak memenuhi kebutuhan tanaman, bobot gabah akan berkurang. Lebih lanjut Supartha et al. (2012) menyatakan bahwa kandungan hara mikro dan makro yang terkandung dalam pupuk kandang dapat meningkatan pertumbuhan tanaman dan hasil gabah per rumpun. 


\section{KESIMPULAN}

Perlakuan jenis pupuk kandang memberikan perbedaan yang nyata terhadap jumlah anakan, jumlah anakan produktif dan bobot gabah kering per rumpun. Pemberian pupuk kandang kotoran ayam pada dosis 10 ton/ha memberikan hasil yang tertinggi pada jumlah anakan, jumlah anakan produktif dan bobot gabah kering per rumpun, dengan potensi hasil 5,77 ton/ha. Pemberian pupuk kandang kotoran sapi dengan dosis 5 ton/ha memberikan hasil terbaik pada bobot 100 gabah kering, dengan potensi hasil 4,04 ton/ha. Pupuk kandang kotoran kambing dengan dosis 5 ton/ha memberikan hasil terbaiik pada tinggi tanaman, umur berbunga, umur panen dan jumlah bulir per malai, dengan potensi hasil 4,94 ton/ha.

\section{DAFTAR PUSTAKA}

Badan Pusat Statistik. (2015). Statistik Indonesia 2015. Badan Pusat Statistik, Jakarta.

De Datta, S.K. (1981). Principle and Practices of Rice Production. A Wiley. Interscience Publication, New York.

Ginting, J., Damanik, B. S. J., Sitanggang, J. M. \& Muluk, C. (2015). Effect of shade, organic materials and varieties on growth and production of upland rice. International Journal of Scientific \& Technology Research, 4(1), 68-74.

Handojo, D. D. (1991). Pupuk dan Pemupukan. Petunjuk dan Teknis Usaha Tani Padi-Itik-Ikan di Sawah. PT Aries Lima, Jakarta.

Hardjowigeno, S. (2003). Ilmu Tanah. Akademika Persindo, Jakarta.

Hoque, M.M., Moynul, M., Hossain, M.M., Khan, M.R.H., Khalequzzaman, K.M. \& Karim, S.M.R. (2003). Effect of varieties of rice and weeding on weed growth and yield of transplant Aman rice. Asian Journal of Plant Sciences, 2(13), 993-998.

Joesron, S. \& Fathorrozi. 2003. Teori Ekonomi Mikro. Salemba Empat, Jakarta.

Kukuh, M \& Anwar, S. (2014). Potensi, Kendala, dan Strategi Pemanfaatan Lahan Kering dan Kering Masam untuk Pertanian (Padi, Jagung, Kedele), Peternakan, dan Perkebunan dengan Menggunakan Teknologi Tepat Guna dan Spesifikasi Lokasi. Fakultas Pertanian IPB. ISBN 979-587-529-9.

Marschner, H. (1995). Mineral Nutrition in Higher Plants. Academic Press, New York.
Mega, T., Ikenaka, T. \& Matsushima, Y. (1970). Studies on N-Acetyl- $\beta$-D-glucosaminidase of Aspergillus oryzae. The Journal of Biochemistry, 68(1), 109-117.

Putra, S. (2012). Pengaruh pupuk NPK tunggal, majemuk, dan pupuk daun terhadap peningkatan produksi padi gogo varietas Situ Patenggang. Agrotrop: Journal on Agriculture Science, 2(1), 55-61.

Rahayu, A. Y. \& Harjoso, T. (2011). Aplikasi abu sekam pada padi gogo (Oryza sativa L.) terhadap kandungan silikat dan prolin daun serta amilosa dan protein biji. Journal of Biota, 16(1), 48-55.

Rosmarkam, A. \& Yuwono, N.W. 2002. Ilmu Kesuburan Tanah. Kanisius, Yogyakarta.

Sari, N.Y., Ete, A. \& Made, U. (2017). Growth response of rainfed lowland rice applied with organic matter in the various condition of water availability. e-J. Agrotekbis, 5(1), 53-57.

Sarif, E. S. (1986). Kesuburan dan Pemupukan Tanah Pertanian. Pustaka Buana. Bandung.

Sarjana, D. G. R. \& Utami. (2001). Analisis pertumbuhan tanaman bawang putih sebagai pengukur keefektifan EM-4 pada beberapa macam seresah. Agritrop, 20(1), 26-31.

Sumartono, Bahrinsamed \& Harjono, R. (1983). Bercocok Tanam Padi. Yasaguna, Jakarta.

Sumardi. (2007). Peningkatan Produksi Sawah Melalui Perbaikan Lingkungan Tumbuh Dalam Meningkatkan Hubungan Source-sink Tanaman pada Metode SRI (The System Rice Intensification). Disertasi. Ilmu - Ilmu Pertanian. Program Pasca Sarjana. Universitas Andalas, Padang. (tidak dipublikasikan).

Supartha, I.N.Y., Wijana, G. \& Andyana, G.M. (2012). Aplikasi jenis pupuk organik pada tanaman padi sistem pertanian organik. EJurnal Agroekoteknologi Tropika, 1(2), 98-106.

Uchida, R. (2000). Essential Nutrients for Plant Growth: Nutrient Functions and Deficiency Symptoms. In: Plant Nutrient Management in Hawaii's Soils, Approaches for Tropical and Subtropical Agriculture. J. A. Silva and R. Uchida. Eds. College of Tropical Agriculture and Human Resources, University of Hawaii at Manoa. Chapter 3. pp.31-55

Utomo, M. (1992). Pembangunan dan Alih Fungsi Lahan. Lampung. Universitas Lampung, Bandar Lampung. 
Warda. (2011). Keragaman Beberapa Varietas Unggul Padi di Kabupaten Bantaeng Sulawesi Selatan. Balai Pengkajian Teknologi Pertanian Sulawesi Selatan. Prosiding Seminar Nasional Serealia. Sulawesi Selatan. pp: 305-312.

Willis, M. (2001). Hama dan Penyakit Utama Tanaman Padi di Lahan Pasang Surut. Monograf. Badan Litbang Pertanian. Balittra, Banjarbaru.
Yitnosumarto, S. (1991). Percobaan Perancangan, Analisis. dan Interpretasinya. PT Gramedia Pustaka Utama, Jakarta.

Yoshida, S. (1981). Fundamental of Rice Crop Science. The International Rice Research Institute. Los Banos, Laguna, Philippines.

Zeany, D.S. (2007). Padi SRI. Pustaka Giratuna, Bandung. 